\title{
Bacillus Calmette-Guérin scar flare after an mRNA SARS-CoV-2 vaccine
}

\author{
Darren Wan-Teck Lim MRCP, Dorothy Hui Lin Ng MBBS-PhD MRCP, Jenny Guek-Hong Low MRCP MPH
}

- Cite as: CMAJ 2021 August 3;193:E1178. doi: 10.1503/cmaj.210696

A

34-year-old woman presented to

our outpatient clinic with swelling and erythema over the site of her childhood Bacillus Calmette-Guérin (BCG) vaccination scar, 7 days after receiving her first dose of the BNT162b2 (PfizerBioNTech) messenger ribonucleic acid (mRNA) vaccine against SARS-CoV-2 on the ipsilateral arm (Figure 1A). She reported associated myalgia and fatigue. The BNT162b2 vaccination site was not inflamed. The second dose of vaccine was completed without incident.

A 45-year-old woman presented to our outpatient clinic with erythema and swelling of her BCG scar on the contralateral arm 4 days after receiving her second dose of the BNT162b2 mRNA vaccine (Figure 1B). The BNT162b2 vaccination site was not inflamed, and her second dose was completed without incident.

In both cases, the swelling and erythema of the BCG scar resolved spontaneously within 7 days, without further treatment.

Sporadic cases of BCG scar inflammation were recently reported after second doses of the mRNA-1273 (Moderna) and BNT162b2 mRNA vaccines, and they followed a similar clinical course to that of our patients. ${ }^{1}$ The mechanism of inflammation is not known. We postulate that it could result from $\mathrm{T}$ cell bystander stimulation by vaccine-induced immune activation. Reactivation of the BCG scar has been described with influenza vaccination, childhood Kawasaki disease and viral infections; ${ }^{2,3}$ hence it is possible that non-mRNA-based SARS-CoV-2 vaccines could lead to similar reactions. Immune crossreactivity of the lipid nanoparticles in mRNA-based vaccines against the lipid-rich mycobacterial cell wall is plausible, although we are not aware of data to suggest that such molecular mimicry occurs.

This phenomenon is likely to be under-reported. However, BCG scar flares after vaccination with current mRNA vaccines against SARS-CoV-2 appear to be benign, as in the cases presented here, and should not alarm physicians, limit vaccinations, nor be a reason for vaccine hesitancy.

\section{References}

1. Lopatynsky-Reyes EZ, Acosta-Lazo H, Ulloa-Gutierrez R, et al. BCG scar local skin inflammation as a novel reaction following mRNA COVID-19 vaccines in two international healthcare workers. Cureus 2021;1313:e14453.

2. Chavarri-Guerra Y, Soto-Perez-de-Celis E. Erythema at the bacillus CalmetteGuerin scar after influenza vaccination. Rev Soc Bras Med Trop 2019;53:e20190390. doi: 10.1590/0037-8682-0390-2019.

3. Kakisaka Y, Ohara T, Katayama S, et al. Human herpes virus type 6 can cause skin lesions at the BCG inoculation site similar to Kawasaki disease. Tohoku J Exp Med 2012;228:351-3.

\section{Competing interests: None declared.}

This article has been peer reviewed.

The authors have obtained patient consent.

Affiliations: Duke-NUS Medical School (Lim); Singapore General Hospital (Ng); Programme in Emerging Infectious Diseases (Low) Duke-NUS Medical School; Infectious diseases (Low), Singapore General Hospital, Singapore.
Content licence: This is an Open Access article distributed in accordance with the terms of the Creative Commons Attribution (CC BY-NC-ND 4.0) licence, which permits use, distribution and reproduction in any medium, provided that the original publication is properly cited, the use is noncommercial (i.e., research or educational use), and no modifications or adaptations are made. See: https://creativecommons.org/licenses/by-nc-nd/4.0/

Correspondence to: Darin Wan-Teck Lim,dmolwt@nccs.com.sg 